\title{
An analytical evaluation of Aviation English textbook
}

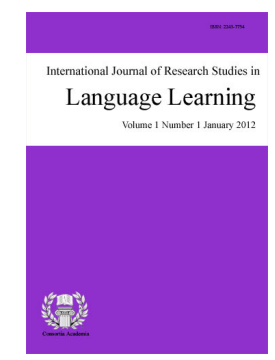

ISSN: $2243-7754$ Online ISSN: 2243-7762

OPEN ACCESS

Baghi, Bibi Ashraf

Ferdowsi University of Mashhad, Iran (bibiashrafbaghi@yahoo.com)

\section{Abstract}

The importance of textbooks in language teaching and language learning is undeniable. Due to the significance of English language teaching to the Iranian air traffic controllers as foreign language learners and the highly sensitive role they play in people's everyday life, the present study is to shed more light on the role of a textbook mainly applied in educating these officers. This study carried out an evaluation of an ESP (English for specific purposes) book in the field of aviation called Aviation English for ICAO (international civil aviation organization) compliance by Macmillan publications. The evaluation of this textbook is performed on two phases of impressionistic overview and in-depth evaluation. For this purpose a series of checklists from Alan Cunningsworth (1995) in his book, choosing your course-book, were used. The results suggested that Aviation English follows a topical and functional syllabus aiming at improving aviators' speaking and listening skills. Moreover, this ESP book integrates interactive activities in all parts of its units (pronunciation, vocabulary, and functions).

Keywords: textbook evaluation; English for specific purposes (ESP); syllabus; Aviation English for ICAO; air traffic controller; foreign language learners, impressionistic overview; in-depth evaluation 


\section{An analytical evaluation of Aviation English textbook}

\section{Introduction}

In three accidents in aviation history (one collision on the ground, one accident involving fuel exhaustion and one controlled flight into terrain) over 800 people lost their lives. What these seemingly different types of accidents had in common was that insufficient English language proficiency on the part of the flight crew or the controller had played a contributing role in the chain of events leading to the accident. In addition to these high-profile accidents, multiple incidents and near-misses as a result of language problems are reported annually, instigating a review of communication procedures and standards worldwide.

As an example of the insight that linguists can bring to bear on our understanding of aviation communication and the consequential implications for training is the case of a message uttered by the first officer in one of the two aircraft involved in a catastrophic collision. His use of the phrase we are now at take-off was interpreted by the aerodrome controller to mean that the aircraft was waiting at the take-off point. Subsequent events demonstrated that the first officer in fact meant that the aircraft had already started the take-off role. linguistic analysis of this accident customarily attribute the ambiguity of the phrase to the phenomenon of linguistic interference from the speaker's mother-tongue which allowed the use of a proposition(equivalent to English at) associated with the infinite form of a verb to express the notion of an action being performed at the moment of speaking. This is not the case in English. The data in this case certainly support that a better mastery of Basic English syntax by the first officer at the moment in time may have helped to alert the controller to the impending collision. However a closer look at the problem raises certain doubts about how clear-cut this solution is. The English language does in fact aloe phrases on the modal AT+NOUN to express the notion that the speaker is currently participating in an activity. To extend this language pattern to the action take-off is therefore not entirely unreasonable. What was missing in the first officer knowledge was the awareness that such phrases may sit astride a semantic fault-line (CURRENT ACTION vs. CURRENT POSITION) which is of critical importance to the specific domain of aircraft movement on the ground (aircraft accident and incident investigation, 2001).

What came above shows how different and demanding aviation English (AE) is from general English (GE) and other ESP as well. Here to be proficient at English equates to be a life saver.

One of the features of $\mathrm{AE}$ is its radiotelephony communications. This form of communication, like telephone communication, lacks the facial cues, body language. And listening cues found in usual face-to-face situations. Communication without such cues is considered to be more difficult and challenging, requiring a higher degree of language proficiency than do face-to-face interactions. In addition, other features of radiotelephony communications make it a unique kind of communicative event. The sound quality may be poor, with distracting background noises. The communicative workload of the air traffic controller (ATC) or a pilot may be heavy, with a corresponding need for efficiency and brevity. In addition to the communicative tasks to which they must attend, pilots must also attend to all of tasks involved in operating their aircraft. A proficient speaker of AE is one who can communicate effectively by radiotelephone in any unexpected situation.

After realizing how language proficiency plays such an important role in AE in 2004, international civil aviation organization (ICAO) required all contracting states to help their ATCs to reach and maintain operational level four before March 2008. ICAO rating scale includes the following language components: pronunciation, structure, vocabulary, fluency, comprehension, and interaction.

The language proficiency requirements for AE apply to speaking and listening proficiency only, and do not address the ability to read and write. The case that ATCs and pilots need reading and writing proficiency to some degree has been made but speaking and writing proficiency were seen as the areas needing more critical address. 
Table 1

Pre-operational, Elementary, Pre-elementary and Operational Levels

\begin{tabular}{|c|c|c|c|}
\hline Level & Pronunciation & Structure & Vocabulary \\
\hline $\begin{array}{c}\text { Operational } \\
4\end{array}$ & $\begin{array}{l}\text { Pronunciation, stress, rhythm, } \\
\text { and intonation, are influenced } \\
\text { by the L1 but only sometimes } \\
\text { interfere with ease of } \\
\text { understanding. }\end{array}$ & $\begin{array}{l}\text { Basic grammatical structures } \\
\text { and sentence patterns are used } \\
\text { creatively and are usually well } \\
\text { controlled. Errors may occur, } \\
\text { particularly in unusual or } \\
\text { unexpected circumstances, but } \\
\text { rarely interfere with meaning. }\end{array}$ & $\begin{array}{l}\text { Vocabulary range and accuracy } \\
\text { are usually sufficient to } \\
\text { communicate effectively on } \\
\text { common, concrete, and } \\
\text { work-related topics. } \\
\text { Can often paraphrase } \\
\text { successfully when lacking } \\
\text { vocabulary in unusual or } \\
\text { unexpected circumstances. }\end{array}$ \\
\hline $\begin{array}{c}\text { Pre-operational } \\
3\end{array}$ & $\begin{array}{l}\text { Pronunciation, stress, rhythm, } \\
\text { and intonation, are influenced } \\
\text { by the L1 and frequently } \\
\text { interfere with ease of } \\
\text { understanding. }\end{array}$ & $\begin{array}{l}\text { Basic grammatical structures } \\
\text { and sentence patterns } \\
\text { associated with predictable } \\
\text { situations are not always well } \\
\text { controlled. Errors frequently } \\
\text { interfere with meaning. }\end{array}$ & $\begin{array}{l}\text { Vocabulary range and accuracy } \\
\text { are often sufficient to } \\
\text { communicate on common, } \\
\text { concrete, or work-related } \\
\text { topics, but range is limited and } \\
\text { the word choice often } \\
\text { inappropriate. Is often unable } \\
\text { to paraphrase successfully } \\
\text { when lacking vocabulary. }\end{array}$ \\
\hline $\begin{array}{c}\text { Elementary } \\
2\end{array}$ & $\begin{array}{l}\text { Pronunciation, stress, rhythm, } \\
\text { and intonation, are heavily } \\
\text { influenced by the L1 and } \\
\text { usually interfere with ease of } \\
\text { understanding. }\end{array}$ & $\begin{array}{l}\text { Shows only limited control of a } \\
\text { few simple memorized } \\
\text { grammatical structures and } \\
\text { sentence patterns. }\end{array}$ & $\begin{array}{l}\text { Limited vocabulary range } \\
\text { consisting only of isolated } \\
\text { words and memorized phrases. }\end{array}$ \\
\hline $\begin{array}{c}\text { Pre-elementary } \\
1\end{array}$ & $\begin{array}{l}\text { Perform at a level below the } \\
\text { Elementary level. }\end{array}$ & $\begin{array}{l}\text { Performs at a level below the } \\
\text { Elementary level. }\end{array}$ & $\begin{array}{l}\text { Performs at a level below the } \\
\text { Elementary level. }\end{array}$ \\
\hline Level & Fluency & Comprehension & Interaction \\
\hline $\begin{array}{c}\text { Operational } \\
4\end{array}$ & $\begin{array}{l}\text { Produces stretches of language } \\
\text { at an appropriate tempo. There } \\
\text { may be occasional loss of } \\
\text { fluency on transition from } \\
\text { rehearsed or formulaic speech } \\
\text { to spontaneous interaction, but } \\
\text { this does not prevent effective } \\
\text { communication. Can make } \\
\text { limited use of discourse } \\
\text { markers or connectors. Fillers } \\
\text { are not distracting. }\end{array}$ & $\begin{array}{l}\text { Comprehension is mostly } \\
\text { accurate on common, concrete, } \\
\text { and work related topics when } \\
\text { the accent or variety used is } \\
\text { sufficiently intelligible for an } \\
\text { international community of } \\
\text { users. When the speaker is } \\
\text { confronted with a linguistic or } \\
\text { situational complication or an } \\
\text { unexpected turn of events, } \\
\text { comprehension may be slower } \\
\text { or require clarification } \\
\text { strategies. }\end{array}$ & $\begin{array}{l}\text { Responses are usually } \\
\text { immediate, appropriate, and } \\
\text { informative. Initiates and } \\
\text { maintains exchanges even } \\
\text { when dealing with an } \\
\text { unexpected turn of events. } \\
\text { Deals adequately with apparent } \\
\text { misunderstandings by checking } \\
\text { confirming, or clarifying. }\end{array}$ \\
\hline $\begin{array}{c}\text { Pre-operational } \\
3\end{array}$ & $\begin{array}{l}\text { Produces stretches of language, } \\
\text { but phrasing and pausing are } \\
\text { often inappropriate. Hesitations } \\
\text { or slowness in language } \\
\text { processing may prevent } \\
\text { effective communication. } \\
\text { Fillers are sometimes } \\
\text { distracting. }\end{array}$ & $\begin{array}{l}\text { Comprehension is often } \\
\text { accurate on common, concrete, } \\
\text { and work related topics when } \\
\text { the accent or variety used is } \\
\text { sufficiently intelligible for an } \\
\text { international community of } \\
\text { users. May fail to understand a } \\
\text { linguistic or situational } \\
\text { complication or an unexpected } \\
\text { turn of events. }\end{array}$ & $\begin{array}{l}\text { Responses are sometimes } \\
\text { immediate, appropriate, and } \\
\text { informative. Can initiate and } \\
\text { maintain exchanges with } \\
\text { reasonable ease on familiar } \\
\text { topics and in predictable } \\
\text { situations. Generally } \\
\text { inadequate when dealing with } \\
\text { an unexpected turn of events. }\end{array}$ \\
\hline $\begin{array}{c}\text { Elementary } \\
2\end{array}$ & $\begin{array}{l}\text { Can produce very short, } \\
\text { isolated, memorized utterances } \\
\text { with frequent pausing and a } \\
\text { distracting use of fillers to } \\
\text { search for expressions and to } \\
\text { articulate less familiar words. }\end{array}$ & $\begin{array}{l}\text { Comprehension is limited to } \\
\text { isolated, memorized phrases } \\
\text { when they are carefully and } \\
\text { slowly articulated. }\end{array}$ & $\begin{array}{l}\text { Response time is slow and } \\
\text { often inappropriate. Interaction } \\
\text { is limited to simple routine } \\
\text { exchanges. }\end{array}$ \\
\hline $\begin{array}{c}\text { Pre-elementary } \\
1\end{array}$ & $\begin{array}{l}\text { Performs at a level below the } \\
\text { Elementary level. }\end{array}$ & $\begin{array}{l}\text { Performs at a level below the } \\
\text { Elementary level. }\end{array}$ & $\begin{array}{l}\text { Performs at a level below the } \\
\text { Elementary level. }\end{array}$ \\
\hline
\end{tabular}

Note. ICAO language proficiency rating scale (found in the attachment of ICAO Annex 1)

Textbooks are important resources for teachers in assisting students to learn every subject including English. They are the foundation of school instruction and the primary source of information for teachers. Hutchinson and 
Torres (1994) suggest that the textbook is an almost universal element of English language teaching and no teaching-learning situation, it seems, is complete until it has its relevant textbook.

Textbook evaluation is an applied linguistic activity through which teachers, supervisors, administrators and materials developers can "make judgments about the effect of the materials on the people using them" (Tomlinson, et al 2001, p. 15). McGrath (2002) believes that textbook evaluation is also of an important value for the development and administration of language learning programs. Cunningsworth (1995) states that although the content of ESP books may look very different from that of general course-books, and the skills being developed may have a different balance from those in general course-books, the guidelines for the evaluation of GPE textbooks also apply to ESP materials. We should check that ESP materials meet learners' needs and the language taught matches the language that the students will use ( $p$ 132).

After ICAO deadline, a widely used AE textbook has been published by Macmillan publication called "Aviation English for ICAO compliance". This book is aimed at professionals already working in the field and at students of the subject, so some prior knowledge is assumed. As the authors claim, it is free standing, primarily intended either as self-study material or for classroom use. As far as the researchers know, no evaluation has been carried out on this textbook. Taking into account the ICAO rating scale, the researchers attempt to see how this ESP book deals with six areas of pronunciation, structure, vocabulary, fluency, comprehension, and interaction.

\subsection{Objectives}

Taking into consideration the crucial role of language proficiency and its unique features in aviation, the researchers attempt to evaluate the defined areas of language proficiency for ICAO rating scale. The present study believes that having a greater knowledge of materials development can help teachers, ATCs, pilots, ESP textbook developers and the aviation authorities to find new ways for improving the quality of textbooks and consequently the quality of teaching and learning.

As such, this study takes two approaches in the evaluation of this book, impressionistic overview and in-depth evaluation and seeks answers to the following questions:

$>\quad$ What significant features stand out just by looking through the book (impressionistic overview)?

$>$ How are six areas of pronunciation, structure, vocabulary, fluency, comprehension, and interaction are dealt with in Aviation English textbook communicatively (in-depth evaluation)?

\section{Method}

\subsection{Material}

The material of this study is an ESP textbook in the field of aviation called "Aviation English for ICAO compliance" by Henry Emery and Andy Roberts. The book is aimed at developing communication skills for pilots and ATCs. It is clearly assumed that students have a fair degree of professional knowledge and experience. The book contains 12 units ordered based on different topics ATCs and pilots may encounter while in the workplace.

\subsection{Instruments}

To conduct the evaluation, a series of checklists from a book by Alan Cunningsworth, choosing your course-book, was used. Two approaches to evaluation are introduced in this book, Impressionistic overview and in-depth evaluation. This paper takes these two approaches on board to evaluate AE textbook. 


\section{Analysis and discussion}

\subsection{Impressionistic overview}

The materials are primarily aimed at developing communication skills for pilots and air traffic controllers rather than the teaching of professional terminology. The aims of the course-book are explicitly set out in the introduction. Unlike many other ESP textbooks, especially EAP books, the quality of the book is excellent. The red-color cover of the book with the picture of an aircraft during landing is really eye-catching. Accompanying pictures, at least two in each page, adds to the spice of the book. There exist maps, comics, colored pages and colored-scripts in almost every page. The general lay-out of the book is clear and attractive. The content map of the book in colored columns shows the topic and subsections of every lesson. The ICAO rating scale is set out in detail in the book (pp. vi and vii).

Units are developed around a number of mainly non-routine and emergency situations (fire, weather, security, and so on) and are then broken down into aviation subtopics, language skills, pronunciation (obviously of crucial importance and with its own separate $\mathrm{CD}$ ), language functions, and topic-related vocabulary. There is, then, a considerable amount of explicit language practice. All these features derive from the ICAO proficiency scale, albeit with different labels, in the process of being interpreted as learning material. The materials can in principle be used either for independent study or in the classroom.

Each unit is divided into four two-page sections. Sections one, two and three have different topics related to the main topic of the unit and Section four which is named language development throughout the book acts like a workbook devoted to practices in functions and vocabularies covered in each unit. Listening scripts are available at the end of the book. There are also nine pages (pp. 104 to 112) for pair-work activities. Unfortunately there is not a vocabulary index with pronunciation guide in phonetic script.

\subsection{In-depth evaluation}

For in-depth evaluation five areas including pronunciation, functions (structure), vocabulary, listening and speaking which are covered throughout the book to meet ICAO requirements are taken into consideration.

Pronunciation - In the aviation English, there is no need for native-like pronunciation. It is assumed a dialect and/or accent intelligible to the aeronautical community. Put it another way, it is the global aspect of phonology that is the concern of AE.

Throughout aviation English book these areas of pronunciation have been covered: ICAO alphabet, numbers, regular past tense endings, /b/ \&/p/, sentence stress, word endings, tonic stress, consonant clusters, intonation of lists, $/ 1 / \&$ stress, -tion -sion -cion endings, information groups and stress, long and $/ \mathrm{r} /, / \mathrm{J} / / \mathrm{z} / / \mathrm{d} z / \& / \mathrm{t} \int /$, information groups, diphthongs, contrastive short vowels. It seems that these selected areas were considered by the authors where misunderstandings happen can most easily occur.

The pronunciation practice of each section has more or less three different parts. The following table shows the distribution of pronunciation activities throughout the 12 units of this book:

Table 2

Pronunciation Activities

\begin{tabular}{cccc}
\hline $\begin{array}{c}\text { Recognition } \\
\text { (in the form of task completion) }\end{array}$ & Listen and repeat & Pair work & $\begin{array}{c}\text { Task-based } \\
\text { production }\end{array}$ \\
\hline 12 & 11 & 8 & 6 \\
\hline
\end{tabular}

As table 2 illustrates the approach of the book toward teaching pronunciation is task-based and 
communicative in a way that in almost all units there are at least two task-based activities in this section (individual or pair-work tasks). It also illustrates that the book integrates both perception and production as equal components in pronunciation training. Recognition activities as task completion are included in all units. Production activities divided to individual and pair work together include 14 cases.

As learners are not going to study phonology in depth, phonological terminologies are not treated broadly and just restricted to stress, consonant clusters, intonation and diphthongs. Maybe inclusion of phonetic alphabet just for diphthongs (unit-11) is not enough for such a globally used ESP book. As this textbook is designed for intermediated and advanced students to be used as a reference source, it would be more beneficial if other phonetic alphabet were also included. Another thing which should be noted is that in the pronunciation section of unit six devoted to intonation, just the intonation of lists has been referred to and ignored, or maybe taken for granted, the intonation patterns of WH and yes/no questions, although the frequency usage of the latter in any kind of conversation is more than the former.

Creating an awareness of the importance of pronunciation is one of the string points of this book. In the CD-ROMs there are numerous occasions where misunderstandings occur due to poor pronunciation on the part of the pilot or ATC. This motivates the learners to improve their pronunciation to defined ICAO standards. As Acton (1984) states drills can be made more lively and memorable by concentrating not just on oral and aural modalities, but also including visual representations and training in the awareness of kinesthetic sensation. In presenting sentence stress and tonic stress, the book make use of distinct- color circles to highlight these features. Intonation patterns are also accompanied by some arrows to make them more memorable. Another positive point about pronunciation practices is that they are integrated into broader communicative activities such as pair work discussions in which students have to use the newly learned materials in their speaking and also hear them in other listening parts of the book.

Functions (structure) - In aviation English, relevant grammatical structures and sentence patterns are determined by language functions appropriate to the task which contribute to the goal of aviation context. In another words, grammar is disguised as functions. For example in unit one page 13 we can see how present continuous is introduced through functional English of describing actions and position: I'm facing kilo, There are signs showing the runways, There is somebody taking off.

Throughout the 12 units of this book, 35 functions assumed to be necessary in aviation communication have been covered. Some grammatical points presented through these functions are as follows: Question forms (asking for information), Modal auxiliary: should (suggesting solution to problems), In order to (expressing purpose), Going to (saying intentions), etc.

Two grammatical points are presented in each unit. Both language use and language form are emphasized. First students are presented with language form and then practice it in meaningful activities such as pair work. Disguising grammatical items in functions with comprehensible contextualization lead learners to understand and internalize their underlying meaning. Further practice is given in the language development section of each unit. The following table indicates the frequency of different activities for functional English throughout the book:

Table 3

Functional English Activities

\begin{tabular}{lclc}
\hline \multicolumn{1}{c}{ Activities } & Frequency & \multicolumn{1}{c}{ Activities } & Frequency \\
\hline Gap filling & 52 & Underlining the correct form & 13 \\
Rearranging scrambled sentences & 9 & Writing activity & 4 \\
Pair-work (discussion) & 30 & Changing one form to another & 4 \\
Matching & 7 & Listen and choose & 1 \\
Listen and repeat & 2 & & \\
\hline
\end{tabular}


Almost all Gap filling activities which outnumber all other exercises in functional English practices refer students back to a previous text or dialogue in listening activities to complete the sentences. This shows the integrative nature of AE practices in different language items it covers. In addition, referring back to previous works to complete sentences in functional English part adds language-awareness dimension prior to the task. Through these consciousness raising activities, learners will develop an explicit knowledge of the grammar of the language which facilitates their ability to communicate. After students develop an explicit knowledge about the aimed grammatical rule, they perform a pair work discussion (task) to use the newly learned functions to reach a specified goal by relating those functions to their own real life and work experiences. It shows that accuracy activities such as drills and grammatical practices are replaced by fluency activities based on interactive pair works (the importance of fluency in ICAO rating scale). Brown (2001) states "a core component of fluency-based pedagogy is task work" (p. 195). Other activities such as matching, underlining one form or the other, rearranging scrambled sentences, and many others, are other dimension or language awareness after task performance.

The general approach of the book toward grammar teaching is inductive. From these 35 grammatical items embedded in language functions only six of them are explained very briefly explicitly. For example when the authors present the function for expressing necessity through the use of 'need to' they add the following brief explanation: "we use 'need + to' verb when it is necessary to do something."

As table 3 illustrates there are two listen and repeat activities in teaching functions in this book that seems in contrast with the communicative approach of $\mathrm{AE}$. These two activities are included into functional language to make students notice how ' $t o$ ' is pronounced in expressing preferences (unit 4) and how to use intonation for polite requesting (unit7).

Vocabulary - Dudley-Evans and Jo St John (1998) maintain that the teaching of vocabulary in ESP follows similar general principles to those in EGP (P, 83). One of the items in ICAO rating scale is vocabulary. As table 1 illustrates in operational level 4, ATCs and pilots must be able to use sufficient and work-related vocabulary to communicate and to paraphrase successfully when lacking vocabulary in unusual or unexpected circumstances. Vocabulary learning is central in aviation English and it is included in its own right. As the book is topic-based, each unit deals with a topic ATCs and pilots may encounter unexpectedly while in work. Each topic brings with itself specific vocabularies such as inhaler, splint, antihistamine and insulin under the topic of medical emergencies or roll, yaw, pitch and tip under the topic of gravity. Each lesson devotes at least two parts to vocabulary. In all 12 units 27 sections come under the 'vocabulary' headline.

According to Hunt and Beglar (1996) there are three approaches to vocabulary instruction and learning: incidental learning( extensive reading and listening), explicit instruction(diagnosing the words learners need to know, presenting the words for the first time, elaborating word knowledge, and developing fluency with known words), and independent strategy development(practicing guessing from content and training learners to use dictionaries). As aviation English textbook is designed to meet ATCs and pilots' communicative needs in unusual situations, vocabularies they require are presented in this book as far as possible. New vocabularies are presented situationally in each unit. There are some contexts (reading and listening) in which these newly presented vocabularies can be visited and after that students try to exploit them in task-based pair-work activities so the approach toward presenting vocabulary in this ESP book is explicit instruction.

Vocabularies are presented in a structured and purposeful way. They are interwoven in listening, speaking, reading and functional activities. Each unit in this book starts with a reading, not for the sake of reading practice but for vocabulary learning in context and also for providing language input for oral activities that form the basis for communicative tasks. Students can use bolded vocabularies in readings to interact with each other's in further communicative activities of the book.

Existence of various kinds of maps about airports layout, many pictures and visual images on concrete vocabularies help students to store and retrieve these words and use them in their interactions. Throughout the 
Khosravany Fard, H., Khosravany Fard, H., Khosravany Fard, A., \& Baghi, B. A.

book these exercises have been used for vocabulary learning:

Table 4

Vocabulary Learning Exercises

\begin{tabular}{lclc}
\hline \multicolumn{1}{c}{ Activities } & Frequency & \multicolumn{1}{c}{ Activities } & Frequency \\
\hline Gap filling (lexical phrases) & 4 & Sentence completion & 3 \\
Synonym matching & 6 & Listen and choose & 8 \\
Using maps \& pictures & 5 & Pair-work discussions & 9 \\
Grouping & 2 & Rearranging scrambled letters & 12 \\
Definition matching & 4 & & \\
\hline
\end{tabular}

As table 4 shows different strategies have been used for vocabulary practice and students can pick whichever fits them best to internalize new words. Every lesson includes a part in which learners are given opportunities to discuss about some questions in which they are prompted to use the newly learned vocabularies to develop fluency in their usage. Moreover, the listen and choose sections presented in almost all vocabulary exercises make students familiar with the context in which the vocabularies are used. Maybe the only weak point in this ESP textbook is the lack of a vocabulary list (glossary) with their phonetic description. As this book may be used as a reference book and the target students are at intermediate and advanced levels, inclusion of a glossary of words with their phonetic description is advisable.

Listening - In ICAO rating scale listening ability is identified as comprehension. An ATC or pilot at operational level 4 must be able to comprehend work-related topics when the accent or variety used is sufficiently intelligible for an international community of users. Aviation English is accompanied by CD-ROMs which provide interactive practice in authentic aviation situations. Most audio materials include the features of radiotelephony communication (background noises, difficulty of communication, aircraft engines sound, and many others) and a wide variety of accents (British, Africans, Arabs, and many others) to provide the most authentic materials as possible in order to meet the needs of international community of ATCs and pilots. There are 77 listening activities throughout the book which are interwoven in listening, speaking, pronunciation, functions and vocabulary sections. All listening activities are preceded by schema-building activities such as reading, vocabulary, pictures, maps and pair or group work discussions to prepare learners for the listening task to come.

Aviation English includes these activities throughout the book:

\section{Table 5}

Listening Activities

\begin{tabular}{lclc}
\hline \multicolumn{1}{c}{ Activities } & Frequency & \multicolumn{1}{c}{ Activities } & Frequency \\
\hline Listen and complete & 4 & Listen and draw & 2 \\
Listen and match & 5 & Listen and choose & 6 \\
Pair-work discussion after listening & 16 & Listen and decide true or false & 3 \\
Listen \& underline the correct word & 13 & Listen and take note & 6 \\
Listen and mark on a diagram & 2 & & \\
\hline
\end{tabular}

As table 5 shows different listening activities and tasks are included in the book (one text with different instructions each time). These different activities include both bottom-up and top-down processing. As listening for specific information is more important in aviation English than listening to get the gist, bottom-up listening activities outnumber top-down ones. In other words, the book adopts a task-oriented approach in which students initially listen for specific information and then involves them in some top-down exercises.

John Field (1996) states that more effective than traditional comprehension questions is the current practice of providing a task where learners do something with the information they have extracted from the text (p. 224). As table 5 illustrates aviation English includes tasks such as drawing, gap filling, labeling, and matching which prompt students to do something with the information they get from the listening materials. In practice, students 
An analytical evaluation of Aviation English textbook

are directed to listen to taped dialogues or short passages and afterwards to act them out in different ways. These tasks provide a more reliable way of checking the understanding because they keep extraneous reading or writing to a minimum.

Listening can prove an isolating activity, in which the liveliest and most vocal class can quickly become a group of separate individuals, each locked up in their own auditory effort. The solution is to play a short passage, then get learners to compare their understanding of it in pairs (John Field, 1995, p. 225). Another strong point about listening activities in aviation English is the inclusion of pair-work discussions after most comprehension tasks. In another words, aural materials are used in productive activities as background or as input for interaction.

As stated before, the main purpose of this book is improving aviators' interaction ability by emphasizing on speaking and listening skills. The present ESP book contains 120 pair-work interaction activities integrated in all sections of each lesson, prompt students to speak. Learners have opportunities for meaningful communicative behavior about relevant topics by using learner-learner interaction as the key to teaching language for communication. Elements of unpredictability and uncertainty in the interactive activities improve students' proficiency to handle unexpected situations while in work.

It seems that one of the difficulties faces the authors in designing interactive activities in this book is the presence of both verbal and non-verbal language in the classroom atmosphere. As mentioned before one of the problematic areas in aviation communication is the lack of nonverbal cues in interaction through microphone. Although some students who take the course of aviation English are practicing professionals, other students who take the course as pre-service learners must be informed of the fact that aviation English requires more proficiency on the part of the learners in work-related areas than GPE.

There are four kinds of activities in speaking sections of this text-book:

\section{Table 6}

Speaking Activities

\begin{tabular}{cccc}
\hline Discuss some questions & State agreement/disagreement & Comparing ideas & Role playing \\
\hline 15 & 5 & 17 & 10 \\
\hline
\end{tabular}

All of the activities defined for speaking practice include an element of unpredictability. By doing activities inserted in table six, students can gain confidence in participating in conversation whilst in the relative safety of the classroom and can develop strategies for coping with the unpredictability involved (cunningsworth, 1995, $p$ 70). These useful activities replicate situations in which conversations take place by creating an information gap. The functions involved in the book help ATCs and pilots to learn strategies and skills of speaking (for example how to give orders, how to give warnings, how to express expectation, and many others).

\section{Conclusion}

This article tried to analyze the kind of materials presented in an ESP textbook called aviation English designed for air traffic controllers and pilots to meet ICAO operational level four. The aim of activities of this book is to help students to reach and maintain ICAO operational level four by emphasizing speaking and listening skills. The book follows a communicative syllabus based on functions and tasks and offers an enormously rich range of activities and opportunities for learning. The presentation in this book is clear and is mostly based on an inductive approach. As activities in different language items and skills of the book indicate, the priority is not given to grammatical accuracy but to fluency in using the language (fluency work has priority over accuracy). The potential for learners' participation is very high. There are lots of pair and group work activities (tasks) during each lesson. Inclusion of varied activities for each section of the book motivates students to go on. Its strength lies in its Integration of listening, speaking, functions, pronunciation, and vocabulary 
Khosravany Fard, H., Khosravany Fard, H., Khosravany Fard, A., \& Baghi, B. A.

activities and avoiding dealing with them in isolation.

The researchers suggest that material designers include a glossary of new vocabularies with straightforward explanations of the terms and their phonetic descriptions to add to the practicality of the book. Although the strong points of the book are numerous, we cannot expect it to contain everything that we want. What we can expect is a sound general coverage and a reasonable balance. Aviation English practitioners often have to plan the course they teach and provide additional materials for it. It is rarely possible to use aviation English textbook without the need for supplementary materials. This book give some general guideline of how to approach aviation English but it cannot cater to the needs of all ATCs and pilots in different parts of the globe with various L1s and different language learning needs. It is the responsibility of the teacher or the sponsor to realize these needs.

It seems that aviation English textbook is different from the GPE course-books in that it focuses on functions more than GPE ones. Widdowson (1983) makes a parallel distinction between two terms, 'competence' and 'capacity': Whereas 'competence' carries with it the implication that behavior is determined by rule almost as if humans simply responded to linguistic . . control, 'capacity' carries with it the assumption that human beings are in control of their own destiny and exploit the rules at their disposal for their own end (p. 8). In other words, a strictly 'training' course deals in the application of formulae, whereas the 'education' end of the continuum allows for creativity and unpredictability in language use. Widdowson is critical of a fully training perspective in ESP because of its reductionist approach to pedagogy, however attractive and apparently cost effective. His pragmatic view is that language education will always have a training aspect, and language training contains some aspects of education. The problem for any ESP course design is to find its place on the continuum (p. 11). The course available for this review illustrates the continuum quite well. The aviation English is probably closest to an 'educational' perspective as it has set its aim to developing language capacity by educating aviators to deal with the aspect of unpredictability in work.

\section{References:}

Acton, W. (1984). Changing fossilized proficiency. TESOL Quarterly, 18(1), 69-83. http://dx.doi.org/10.2307/3586336

Aircraft accident and incident investigation. Annex 13 to the convention on international civil aviation. (2001). Cunningworth, A. (1995). Choosing your course book. Thailand: MacMillan.

Dudley-Evans, T., \& M. J. St. John. (1998). Development in ESP: A multi-disciplinary approach. Cambridge: Cambridge University Press.

Emery, H., \& Roberts, A. (2008). Aviation English for ICAO compliance. London: Macmillan Press.

Hutchinson, T., \& Torres, E. (1994). The textbook as agent of change. ELT Journal, 48(4), 315-328. http://dx.doi.org/10.1093/elt/48.4.315

Manual on the implementation of ICAO language requirements. Document 9835. (2004).

McGrath, I. (2002). Materials evaluation and design for language teaching. Edinburgh: Edinburgh University Press.

Personnel licensing. Annex 1 to the convention on international civil aviation. (2001).

Richards, J. C., \& Renandya, W. A. (2002). Methodology in language teaching: An anthology of current practice. Cambridge: Cambridge University Press. http://dx.doi.org/10.1017/CBO9780511667190

Tomilnson, B. (2003). Developing materials for language teaching. London \& NY: Continuum Press.

Widdowson, H. G. (1983). Learning purpose and language use. Oxford: Oxford University Press. 